\title{
INFLUENCE OF PARENTAL OWNERSHIP STRATEGIES ON THE MANAGEMENT OF ACADEMIC PERFORMANCE IN SECONDARY SCHOOLS IN IMENTI SOUTH SUB-COUNTY, MERU COUNTY, KENYA
}

\author{
Anne Wanjiku Muiru \\ Department of Education, School of Education and Business, Kirinyaga University, Kenya
}

\section{ARTICLE INFO}

Received: 13 December 2021

Revised: 20 February 2022

Accepted: 22 February 2022

Keywords:

Parental Ownership, Strategies,

Management, Academic

Performance

Corresponding Author:

Anne Muiru

Email: amuiru@kyu.ac.ke Copyright $\odot 2022$ by Author(s)

This work is licensed under the Creative Commons Attribution International License (CC BY 4.0). http://creativecommons.org/licenses/ by/4.0/
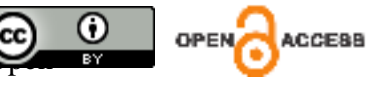

\begin{abstract}
Purpose: The study examined the influence of parental ownership on the management of academic performance in Imenti South Sub County, Meru County, Kenya.

Approach/Methodology/Design: The study adopted a mixed methodology approach and concurrent triangulation design. The target population of the study was a total of 17568 respondents consisting of 16800 students, 48 principals, and 720 teachers. The researcher used stratified sampling to get the 8 principals and purposive sampling to get 720 teachers and 64 students. The researcher used questionnaires and interview schedules to collect data from principals, teachers, and students. Piloting of the research instruments was done in $10 \%$ of the sample size in the neighboring Igembe Sub-County. Validity was measured by face and content validity, while the reliability of research instruments was checked through test and retest method. The reliability coefficient was computed using the Pearson Product correlation coefficient where a coefficient of less than 0.07 was deemed dependable. Qualitative data was analyzed using themes and presented using narratives, while quantitative data was analyzed using SPSS version 21.

Findings: The results indicate that students were not performing well in their academic performance is because many parents are not involved. The study, therefore, recommended that with increased parental engagement through volunteering, ownership, guidance and support, the learners would perform better.

Originality/value: This study has significant value in the sense that if the parents own the schools where their children study, then the academic performance would improve, and at the same time, there would be greater discipline among the learners.
\end{abstract}

\section{INTRODUCTION}

Ensuring quality education is one of the six Education Goals agreed upon by over 160 governments during the Worlds Academic Forum, in Dakar 2000 (UNESCO 2012). The Kenyan government seeks to offer students an education that equips knowledge, skills to enable students to participate in social, political, and economic development (UNESCO 2012). Education has, therefore, become a major concern in the 21 st century in every Continent in the World. The provision of education has been the responsibility of governments worldwide. However, for a country to attain equitable and high-quality standards, the stakeholders need to work together (Worlds Academic Forum, 2000). Parental involvement in schools has become a major education issue. For the last two decades, social 
scientists have raised questions on the influence of parents' involvement on the education outcome of secondary school children.

There is today an increasing concern about the quality of education in every country. States are taking a greater role in monitoring and maintaining academic standards. Communities or societies are more concerned about the expense of public education. Parents are keen on ensuring that their children receive adequate preparation to lead rewarding quality lives and whether secondary schools are concerned about providing quality education (Mau,1997). If parents could own the schools where their children are, they can be concerned about their academic challenges and this can go along way in their performance. Parent school involvement in children's education is associated with positive educational outcomes (Zellman\& Waterman, 1998). In addition, Hill and Taylor (2004) argued that developing collaborations between families and schools promote academic success.

This study is an attempt to examine the influence of parental ownership strategies on the management of academic performance in secondary schools in Imenti South Sub-County, Meru County, Kenya.

\section{LITERATURE REVIEW}

Parental ownership may be different from culture to culture and society to society. Parental ownership may have different types, which might have a differential influence on the academic performance of their children. Parental expectations have a greater impact on students' educational outcomes. Parental ownership may include activities like helping children in reading, encouraging them to do their homework independently, monitoring their activities inside the house and outside the four walls of their house, and providing coaching services for improving their learning in different subjects.

The role of Parental ownership in children's education has become a central issue in educational policy and research (Christenson, 2004; Domina, 2005). Research findings support the existence of a positive relationship between parental ownership and educational success, especially in the secondary school years (Jeynes, 2003; Mncube, 2009; Domina, 2005). However, current knowledge regarding the nature and magnitude of the effects of Parental ownership in secondary education is inconsistent and limited in scope (Singh, Bickley, et al., 1995). Most of the existing research has investigated parental ownership in the primary and middle grades. Less is known about successful Parental ownership in secondary school. The current project seeks to expand knowledge of the different parental practices in secondary education, as well as their effects on the academic success of secondary school students.

Parents play a crucial role in both the home and school environments. In general, Parental ownership is associated with children's higher achievements in language and mathematics, enrolment in more challenging programs, greater academic persistence, better behavior, better social skills and adaptation to school, better attendance, and lower drop-out rates (Henderson \& Mapp, 2002).

\section{Theoretical Framework}

The study was postulated by Joyce Epstein's theory of parent involvement (Epstein et al. (2019) that student involvement as families and communities take an active role in creating a caring educational environment. When parents are involved in school, they are the ones who 
consistently demonstrate parenting skills, communicate with school staff, volunteer their time in school, help their children learn at home, take an active role in school-related decision making, and who collaborate with the school community.

In Epistens opinion, schools and families share the responsibility of socialization of the child. Therefore, her theory of overlapping spheres of influence posits that the work of the most effective families and schools overlap and they share goals and missions. According to Epstein, there are three most important contexts in which the child grows and develops: family, school, and community. Although some practices of school and family are conducted separately, some important things need to be done in conjunction with these contexts reflecting the shared responsibility of parents and educators.

Joyce has developed a framework for defining six types of parental involvement and linking them to a particular outcome. This widely accepted flame work guides and helps educators develop a comprehensive family and school relationship. Educators and parents are encouraged to select the practices that coincide most closely with their goals, needs and capabilities. Epstein emphasized that not all parents' involvement leads to improved student achievement Epstein, et al. (2019). The selected results (produced by each of the six types) as explained below that should help correct the misperception that any practice involving families will improve the children's academic performance. More so, Joyce notes that while certain practices are likely to influence students' test scores; others are designed to produce outcomes related to attitude and behaviors.

\section{METHODOLOGY AND PROCEDURES}

This study used a mixed methodology approach and concurrent triangulation, which refers to an emergent methodology of research that advances the systematic integration or mixing of quantitative and qualitative data within a single investigation or sustained program of inquiry (Creswell \& Clark, 2011). The premise of this methodology is that such integration permits a more complete and synergistic utilization of data than do separate qualitative and quantitative data collection and analysis.

The design used was concurrent triangulation. Here, the participants were given all the instruments concurrently and data was collected qualitatively and quantitatively. Analysis was also done by comparing the two instruments used, that is the questionnaires and the interview schedules, and coming out with results.

\section{Target Population and sample size}

Imenti South Sub County has a total number of 78 secondary schools. The Sub County is characterized by a diversity of schools both public and private schools. The schools are in different categories or levels i.e. National schools: Provincial schools: Sub County schools and day secondary schools. Purposive sampling shall also be used when arriving at various respondents to be used in the study such as principals, teachers. Simple sampling is used for other respondents such as parents, students, and the Board of Governors.

Table 1 : Sample Size

\begin{tabular}{lll}
\hline Category & Population & Sample \\
\hline Principals & 48 & 8 \\
Teachers & 720 & 16 \\
Students & 16800 & 64 \\
Parents & 2058 &
\end{tabular}




\section{Research Instruments}

The study used questionnaires to obtain quantitative data. According to Orodho (2009), a questionnaire is a tool used to collect data, which allows measurement for or against a given perspective and makes it possible for a researcher to gather a significant amount of information within a short span of time. The researcher used structured interviews for principal where the researcher developed an interview guide with questions on research objectives. Secondary documentary materials were also assembled from the schools' documentary files in various schools.

\section{Data Analysis Procedures}

Data synthesized from the instruments were analyzed both qualitatively and quantitatively. Using the same data collected, simple linear regression analysis was applied to determine the joint relationships between the factors (identified through factor analysis) and the dependent variable. T-test and ANOVA were computed to establish if there is a relationship and the nature of the relationship. Qualitative data derived from the interview was analyzed and discussed thematically and presented in narrative forms. This data was used to support the quantitative findings as well as elaborate on the concepts obtained.

\section{RESULTS AND DISCUSSION}

\section{Influence of parental ownership on the management of academic performance in Imenti South Sub County, Meru County, Kenya}

The study is aimed at establishing the influence of parental ownership on the management of academic performance in Imenti South Sub County, Meru County, Kenya. This was rated with a degree of agreement or disagreements i.e. strongly agree (SA), Agree (A), Neither (N), Disagree (D), and Strongly Disagree (SDA).

Table 3: Teachers' view on parents' participation in Decision Making of students' Academic Performance

\begin{tabular}{lll}
\hline Statement & Mean & S. D \\
\hline $\begin{array}{l}\text { Most parents aspire that their daughter get married immediately after } \\
\text { primary schools }\end{array}$ & 3.5 & 0.71611 \\
Parents encourage their daughters to assist in domestic chores after school & 4.5 & 0.71611 \\
Most parents encourage their sons to help in domestic chores after school & 4.625 & 0.49029 \\
Advocacy roles for fortifying links between schools and parents & 3.5 & 0.71611 \\
Most parents give gifts to their children when they perform well in the & 3.5 & 0.71611 \\
examination. & 4.5 & 0.71611 \\
Most students participate actively during my lessons. &
\end{tabular}

\section{Source: Author}

Teachers' views on the above statements were sought, and no statement on whether parents aspire their daughter get married immediately after primary schools, parents encourage their daughters to assist in domestic chores after school, parents encourage their sons to help in domestic chores after school were all strongly disagreed with a mean above 3.0. Advocacy roles for fortifying links between schools and parents, parents giving gifts to their children when they perform well in the examination and whether students participate actively during lessons were all strongly agreed. 
Table 3: Students view on parents' participation in decision making of students' academic performance

\begin{tabular}{lll}
\hline Statement & Mean & S. D \\
\hline My parents aspire me to get married immediately after primary schools & 3.0 & 0.5 \\
My parents encourage me to assist in domestic chores after school & 2.1 & 0.9732 \\
Advocacy roles for fortifying links between schools and parents & 3.2 & 0.4320 \\
My parents give me gifts when I perform well in the examination & 3.0435 & 0.8763 \\
\hline
\end{tabular}

Source: Author

Students' views on the above statements were sought as follows; on the statements of parents aspiring that their daughters get married immediately after primary school and parents encouraging their children to assist in domestic chores after school was strongly disagreed with a mean above 3.0. On advocacy roles for fortifying links between schools and parents and parents giving gifts to their children when they perform well in the examination were strongly agreed with a mean of 3.2 and 3.0 respectively.

The interviewee's opinion on this objective pointed out that parental participation in decisionmaking, when it is a comprehensive program involving parents in learning support activities as well, is associated with improved student outcomes. Parent and community involvement in decision-making may also help make schools more accountable to the community. Parental participation in school decision-making may be strengthened by including parents in school site councils, parent-teacher associations, and other committees. Outcomes from type five activities include the benefits of policies that are enacted on behalf of students. Students are also likely to become aware of family representation in school decisions. Parents are expected to develop opportunities for input, feelings of ownership, an understanding of policies, and a sense of connection with other families.

Inferential Analysis on the Influence of parental ownership on the management of academic performance in Imenti South Sub County, Meru County, Kenya

Table 2 : Parental Involvement in the I.E.P. Formulation

\begin{tabular}{|c|c|c|c|}
\hline & & & $\%$ \\
\hline \multirow{4}{*}{ FREQUENCY } & Pearson & 1 & $1.000^{*}$ \\
\hline & Correlation & & \\
\hline & Sig. (2-tailed) & & .000 \\
\hline & $\mathrm{N}$ & 21 & 21 \\
\hline \multirow{4}{*}{ PERCENTAGE } & Pearson & $1.000^{* * *}$ & 1 \\
\hline & Correlation & & \\
\hline & Sig. (2-tailed) & .000 & \\
\hline & $\mathrm{N}$ & 21 & 21 \\
\hline
\end{tabular}

**. Correlation is significant at the 0.01 level (2-tailed).

Source: Author

The correlation results showed perfect significance hence showing that the percentages were drawn from the frequencies.

Thematic analysis on the on Influence of parental ownership on the management of academic performance in Imenti South Sub County, Meru County, Kenya

For this objective, the researcher interviewed heat teachers who agreed that there was a significant relationship between parental ownership on the management of academic performance. One headteacher observed, 
"Parents who are fully involved in their children academic performance help them achieve more in school; this helps the student to be more independent in learning as they are supported by their parents". (Head teacher 2)

\section{Mixing and interpreting data on parental ownership on management of academic performance}

Interpretation for descriptive, inferential and thematic was mixed and interpreted. It was clear that Parental Involvement influenced academic performance. More has to be done on the involvement of parents in the academic performance of students in secondary school in Imenti sub-county, Meru County., Kenya.

\section{Discussion}

The findings of the study revealed that parents are involved in supporting school-related activities through proving school fees and scholastic materials; disciplining their children and providing them with moral support. However, there is an issue regarding parental participation in the management of the schools that their children attend. It is in this regard that the findings of the study depart from the findings of earlier researchers into parental participation in schools and its implications for school effectiveness. Mncube (2009) stressed that parents in South Africa are not yet playing their full role as governors mandated by legislation. This lack of involvement is also in Ghana as the results of this study suggest.

Specifically, critical consideration of the findings of the study indicates that although the parents are involved in supporting their children's school education in some ways, generally speaking, they are not involved in the management of these schools. At the least, some of the data collected indicated that parents are represented in the school management committees like Parents' Teachers' Associations and Boards of Governors but even then, the school managers prominently deemphasized the contribution of the parents that are appointed to these committees, which further brings to question the role of parents in the management of their children's schools.

The study established that although parents in Imenti South Sub County have been involved in supporting the education of their children, they have not done so in ways that are similar to those enumerated by Nancy and Lorraine (2004). This emphasizes volunteering at school, communicating with teachers and other school personnel, assisting in academic activities at home and attending school events, with which they associate reciprocal benefits for the schools and the parents and, ultimately, good academic performance. This means that, in discussing parental involvement in schools and their performance in Imenti South Sub County, the focus should be shifted from asking as to whether parents have been involved in supporting school activities to asking as to how they have been involved and, ultimately, why they have not been involved in the management of these schools. To this end, the findings of the study are extending the discussion on parental involvement in schools and the schools' performance.

\section{CONCLUSION AND SUGGESTION}

Parents have a role to play in the decision-making of these resources available in schools since they are expected to contribute towards the preparation of their children for academic excellence. Besides the issue of parents supporting their children in school, however, is the issue of parental participation in the management of the schools that their children attend. It is in this regard that the findings of the study depart from the findings of earlier researchers into 
parental participation in schools and its implications for school effectiveness. Specifically, critical consideration of the findings of the study indicates that although the parents are involved in supporting their children's school education in some ways, generally speaking, they are not involved in the management of these schools. At the least, some of the data collected indicated that parents are represented in the school management committees like Parents' Teachers' Associations and Boards of Governors but even then, the school managers prominently deemphasized the contribution of the parents that are appointed to these committees, which further brings to question the role of parents in the management of their children's schools. Government should make a policy directing parents to participate in the management of these schools (on top of supporting the children in the ways that they were found to be supporting them) and parents should make it possible for them to do so. This could be done by encouraging the parents to take up specific roles in school management and indicating the values of their involvement in school management let alone making it possible for them to participate in school managerial activities through conducting the managerial functions in which they are involved in ways and in modes of communication that the parents comfortably understand.

\section{ACKNOWLEDGEMENTS}

I am indebted to my supervisors for their encouragement, valuable suggestions, scientific guidance and brotherly advice during the writing process. I acknowledge all the lecturers who accorded me unreserved support during the entire period of project research.

\section{CONFLICT OF INTEREST}

The author has no affiliations with or involvement in any organization or entity with any financial interest (such as honoraria; educational grants; participation in speakers' bureaus; membership, employment, consultancies, stock ownership, or other equity interest; and expert testimony or patent-licensing arrangements), or non-financial interest (such as personal or professional relationships, affiliations, knowledge or beliefs) in the subject matter or materials discussed in this manuscript.

\section{FUNDING}

This is a self-sponsored study as part of my academic growth

\section{REFERENCES}

Christenson, S. L. (2004). The family-school partnership: An opportunity to promote the learning competence of all students. School psychology review, 33(1), 83-104. https://psycnet.apa.org/doi/10.1521/scpq.18.4.454.26995

Domina, T. (2005). Leveling the home advantage: Assessing the effectiveness of parental involvement in elementary school. Sociology of education, 78(3), 233-249. https://www.jstor.org/stable/4148916

Griffiths, M. D. (1999). Gambling technologies: Prospects for problem gambling. Journal of Gambling Studies, 15, 265-283. https://doi.org/10.1023/A:1023053630588

Garreau, M. C. (1996). Conquering heroes: parents' perspectives of the child's schooling experience after the child's diagnosis of cancer. [Ph.D. Dissertation], University of Alberta.

Epstein J. L. et al.,(2002) School, Family, and Community Partnerships, Cotwin Press. 
Henderson, A. T., \& Mapp, K. L. (2002). A new wave of evidence: The impact of school, family and com-munity connections on student achievement. Southwest Educational Development Laboratory, National Center for Family and Community.

Hill, N. E., \& Taylor, L. C. (2004). Parental school involvement and children's academic achievement: Pragmatics and issues. Current directions in psychological science, 13(4), 161-164. https://doi.org/10.1111\%2Fj.0963-7214.2004.00298.x

Kline .R. (2011). Principles and practices of structural modeling. $3^{\text {rd }}$ Edition. New York. Guilford Press.

Jeynes, W. H. (2003). A meta-analysis: The effects of parental involvement on minority children's academic achievement. Education and urban society, 35(2), 202-218. https://doi.org/10.1177\%2F0013124502239392

Mc Gregor Donald (1960). The Human Side of Enterprise. Graw Hill; New York.

Ministry of Education Science and Technology: Kenya Education Sector Support Programme (2005-2010) .

Moles O. (1993). Families and schools in prurastic society, Albany: State University of New York University.

Mncube, V. (2009). The perceptions of parents of their role in the democratic governance of schools in South Africa: Are they on board?. South African Journal of Education, 29(1), 83-103. http://dx.doi.org/10.1590/S0256-01002009000100006

Mugenda O. and Mugenda A. (2003) Research Methods: Quantitave and qualitative approaches. Nairobi Acts press.

Lareau. A (2011). Unequal Childhoods, Race and Family (2nd ${ }^{\mathrm{Ed}}$ ).Berkeley CA: University of California Press.

Swap. S. (1987). Enhancing parent Involvement in School. New York. Teachers college press.

Schelder. B and Coleman J.S (1993). Parent Involvement In the home, their children and school. Blounder Westview Press.

Singh, K., Bickley, P. G., Trivette, P., Keith, T. Z., et al. (1995). The effects of four components of parental involvement on eighth-grade student achievement: Structural analysis of NELS-88 data. School Psychology Review, 24(2), 299-317. https://doi.org/10.1080/02796015.1995.12085769

Nancy E.and Lorraine (2004) Parental school Involvement and Children Academic achievement. Pragmatics and Issues. Blackwell publishing Ltd.

Thomas J. and Stokton C. (2003). Social economic Status, race and retention: Impacts on students' achievement. Essay in Education, 7.

Zellman, G. L., \& Waterman, J. M. (1998). Understanding the impact of parent school involvement on children's educational outcomes. The Journal of Educational Research, 91(6), 370-380. https://doi.org/10.1080/00220679809597566 